\title{
STUDI PENGALAMAN GURU-GURU MTSN 6 PESISIR SELATAN DALAM PENULISAN KARYA TULIS ILMIAH GUNA MENINGKATAN IPTEK MASYARAKAT SERTA MEWUJUDKAN GURU YANG PROFESIONAL
}

\author{
Fanny Rahmatina Rahim ${ }^{1)}$, Festiyed ${ }^{1)}$, Yohandri ${ }^{1)}$, Yulkifli ${ }^{1)}$, Djusmaini Djamas ${ }^{1)}$ \\ ${ }^{1)}$ Jurusan Fisika, FMIPA Universitas Negeri Padang \\ fannyrahmatinarahim@gmail.com
}

\begin{abstract}
Teachers have an important role in education. To support it, teachers should have good profess sionalism especially in writing articles. In fact, many teachers are not proficient in writing articles because they do not have enough knowledge about it. Teachers need such training for increasing their experience in writing. After that, the progress will be seen. The research method is descriptive quantitative. The data in this research is quantitative data. The type of data is the primary data. A data collection technique in this study is questionnaires. Data processing techniques used include editing, coding, tabulation, and scoring. Data analysis technique is descriptive analysis percentage. After doing the training, the teachers have more knowledge and interest of writing articles.
\end{abstract}

Keywords : Penulisan Karya Tulis Ilmiah, IPTEK, Guru Profesional

\section{PENDAHULUAN}

Salah satu amanat yang tertuang dalam pembukaan UUD 1945 alinea keempat adalah Pemerintah Negara Republik Indonesia dapat mencerdaskan kehidupan bangsa. Harapannya, Indonesia dapat menjadi bangsa yang maju di abad ke 21. Oleh karena itu, Pemerintah Indonesia melalui lembaga pendidikan nasional berkewajiban memenuhi amanat dan harapan tersebut.

Salah satu faktor penentu dari keber hasilan pendidikan di Indonesia adalah guru. Tinggi rendahnya kualitas pendidikan Indonesia ditentukan oleh kualitas guru (Yahya, 2013: 23). Sebagai pilar utama dalam sistem pendidikan nasional, guru mempunyai peran penting dalam proses pembelajaran. Peran seorang guru telah tertuang dalam UUD 1945, sebagai upaya memberantas kebodohan dan mencerdaskan kehidupan bangsa agar tercipta masyarakat Indonesia seperti yang dicita-citakan. Kesukses an dalam proses pembelajaran merupakan cerminan dari kualitas dan keseriusan guru dalam menjalankan peran. Meninjau kepenting an dari peran guru dalam proses pembelajaran, pemerintah telah menerbitkan sejumlah kebijak an untuk mendorong pengembangan profesional isme guru.

Profesi berasal dari bahasa Latin, yaitu profesion yang berarti mampu atau ahli dalam suatu bentuk pekerjaan (Ramayulis, 2013: 27). Dalam KBBI, kata profesi diartikan sebagai pekerjaan yang dikuasai karena pendidikan keahlian (Yahya, 2013: 14). Profesional berarti pekerjaan yang memerlukan keahlian, kemahir an, atau kecakapan yang memenuhi standar mutu (Wiyanto, 2012: 8) serta memerlukan pendidikan profesi (Mudhafir, 2013: 14). Tuntutan guru profesional adalah memiliki kemampuan dan keahlian khusus dalam bidang keguruan sehingga ia mampu melakukan tugas dan fungsinya sebagai guru dengan kemampuan maksimal (Usman, 2011: 15).

Profesi guru harus dikembangkan sebagai profesi yang bermartabat sebagaimana diamanat kan dalam Undang-Undang Nomor 14 Tahun 2005 tentang Guru dan Dosen. Diperlukan suatu sistem pembinaan yang disebut sebagai Pengembangan Keprofesian Berkelanjutan (PKB) sebagai kelanjutan dari jabatan profesi guru. PKB dalam bahasa inggris dikenal sebagai Continous Professional Development (CPD) yang merupakan serangkaian aktivitas reflektif yang dirancang untuk meningkatkan kemampu an, pengetahuan, pemahaman, dan keterampilan guru profesional (Tim Penulis Jurnal Pendidikan Sains, 2013: 160).

Pengembangan profesi guru adalah kegiatan guru dalam rangka pengamalan ilmu pengetahuan, teknologi dan keterampilan untuk peningkatan mutu dan menghasilkan sesuatu yang bermanfaat bagi pendidikan dan kebudaya an. Hasil yang diharapkan dari PKB ini salah satunya adalah guru dapat menghasilkan publikasi ilmiah berupa karya tulis ilmiah. Karya tulis ilmiah guru dapat dipublikasikan dalam bentuk laporan hasil penelitian (misalnya 
laporan PTK). Selain itu, karya tulis ilmiah yang dapat dipublikasikan oleh guru adalah buku pelajaran, modul/diktat pembelajaran, buku dalam bidang pendidikan, dan karya terjemahan (Setiadi, 2015: 31). Penulisan karya ilmiah dapat meningkatkan kemampuan profesionalisme guru sekaligus memperbaiki kualitas pembelajaran yang disampaikannya.

Dalam hal administrasi kepegawaian, kemampuan untuk bisa membuat karya tulis ilmiah ini juga menjadi suatu keharusan bagi para guru yang akan naik pangkat dari golongan IV a ke IV b dan seterusnya. Pada masa yang akan datang, kemampuan untuk membuat karya tulis ilmiah ini menjadi prasyarat yang harus dimiliki oleh seorang guru. Peraturan Menteri Negara Pendayagunaan Aparatur Negara dan Reformasi Birokrasi Nomor PER/16/M.PANRB/11/2009 tentang Jabatan Fungsional Guru dan Angka Kreditnya semakin menegaskan pentingnya karya tulis ilmiah. Kenaikan pangkat dari golongan III b ke III $c$ dan golongangolongan selanjutnya mensyaratkan paling sedikit empat angka kredit dari sub unsur publikasi ilmiah dan/atau karya inovatif.

Karya tulis ilmiah sering disebut juga karangan ilmiah adalah karangan ilmu pengetahuan yang menyajikan fakta dan ditulis menurut metodologi penulisan yang baik dan benar. Suatu karangan dapat dikatakan ilmiah jika ia mengungkapkan suatu permasalahan dengan ilmiah. Karya tulis ilmiah bertujuan untuk menyampaikan gagasan penulis dengan caranya sendiri (Winarto, 2016: 2).

Ada beberapa macam karya tulis ilmiah bagi guru dan angka kreditnya juga bermacammacam. Misalnya, karya ilmiah hasil penelitian, pengkajian, dan atau evaluasi di bidang pendidikan yang dipublikasikan dalam bentuk buku yang diterbitkan secara nasional memiliki angka kredit 12,5 dan dalam majalah ilmiah yang diterbitkan oleh Departemen Pendidikan Nasional memiliki angka kredit 6. Contoh lain, karya ilmiah hasil penelitian yang tidak dipublikasikan tetapi didokumentasikan di perpustakaan sekolah jika dalam bentuk buku memiliki angka kredit 8 sedangkan jika dalam bentuk makalah memiliki angka kredit 4 . Apabila karya tulis berupa tinjauan atau ulasan ilmiah hasil gagasan sendiri dalam bidang pendidikan yang dipublikasikan jika dalam bentuk buku yang ditebitkan dan diedarkan secara nasional setiap karya nilai kreditnya 8 sedang jika dalam bentuk majalah ilmiah yang diakui oleh Departemen Pendidikan Nasional setiap karya adalah 4. Jika karya tulis berupa makalah yang tidak dipublikasikan tetapi didokumentasikan di perpustakaan sekolah dalam bentuk buku setiap buku nilai kreditnya 7, dan jika dalam bentuk makalah nilai angka kreditnya 3,5. Jika tulisan ilmiah populer di bidang pendidikan dan kebudayaan yang melalui massa setiap tulisan yang merupakan satu kesatuan nilai kreditnya 2.

Dengan memahami pentingnya angka kredit penulisan karya ilmiah, guru dapat termotivasi untuk menulis sesering mungkin. Namun pada kenyataannya, dari 26 guru di MTsN 6 Pesisir Selatan, hanya 5 guru yang pernah menulis karya tulis ilmiah. Berdasarkan identifikasi masalah, penulis menemukan be berapa permasalahan yang terjadi pada guru di MTsN 6 Pesisir Selatan. Pertama, kurangnya pemahaman guru MTsN 6 Pesisir Selatan tentang penulisan karya tulis ilmiah. Kedua, kurangnya minat guru-guru untuk menulis karya tulis ilmiah. Melihat kondisi seperti ini, guruguru di MTsN 6 Pesisir Selatan merupakan sasaran yang tepat untuk dibekali pemahaman mengenai penulisan karya tulis ilmiah.

Oleh karena itu, penulis berinisiatif mengadakan suatu kegiatan yang bertujuan untuk meningkatkan pemahaman dan minat guru-guru di MTsN 6 Pesisir Selatan dalam penulisan karya tulis ilmiah. Berdasarkan identifikasi masalah yang dijabarkan di atas dapat dirumuskan permasalahan yang akan dicari solusinya yaitu : "Apakah dengan pembe rian pembekalan dan pendalaman materi tentang penulisan karya tulis ilmiah untuk guru-guru MTsN 6 Pesisir Selatan dapat meningkatkan IPTEK masyarakat dalam penulisan karya tulis ilmiah serta dapat mewujudkan guru yang profesional?"

Berdasarkan latar belakang masalah yang dikemukakan, judul penelitian yang digunakan adalah "Studi Pengalaman Guru-Guru MTsN 6 Pesisir Selatan Dalam Penulisan Karya Tulis Ilmiah Guna Meningkatan Iptek Masyarakat Serta Mewujudkan Guru yang Profesional".

\section{METODE PENELITIAN}

Metode penelitian yang digunakan adalah penelitian deskriptif dengan pedekatan kuantitatif. Metode penelitian ini menurut Sugiyono (2012: 8) yaitu metode yang digunakan untuk meneliti pada populasi atau 
sampel tertetu, pengumpulan data menggunakan instrumen penelitian, analisis data bersifat kuantitatif, dengan tujuan menguji hipotesis yang telah ditetapkan. Objek penelitian ini adalah guru-guru di MTsN 6 Pesisir Selatan.

Data yang digunakan dalam penelitian ini adalah data yang bersifat kuantitatif karena dinyatakan dengan angka-angka yang menunjuk kan nilai terhadap besaran atas variabel yang diwakilkannya. Jenis data yang digunakan dalam penelitian ini adalah data primer. Data primer merupakan data yang diperoleh secara langsung dari objek yang diteliti. Data primer diperoleh dari kuesioner yang dilakukan.

Teknik pengumpulan data dalam peneliti an ini yaitu dengan menggunakan kuesioner. Kuesioner adalah teknik pengumpulan data yang dilakukan dengan cara memberi pernyataan tertulis (Sugiyono, 2012: 142) yang digunakan untuk memperoleh informasi dari responden dalam arti laporan tentang pribadi atau hal-hal yang ia ketahui. Kuesioner dalam penelitian ini diberikan kepada 26 guru mengenai umpan balik setelah diberikan pembelakan dan pendalaman materi.

Teknik pengolahan data yang digunakan meliputi kegiatan editing, coding, tabulasi, dan scoring (Misbahudin, 2013: 32). Editing dalam penelitian ini yaitu mengoreksi kuesioner penelitian yang telah disebar. Coding yaitu memberikan kode terhadap kuesioner yang akan dianalisis, dari 26 kuesioner yang telah disebar diberikan angka 1-26 yang membedakan jawaban dari tiap responden. Tabulasi yaitu jawaban dari kuesioner yang telah disebar dimasukkan ke dalam tabel sesuai dengan analisis. Scoring yaitu jawaban dari pertanyaan yang terdapat dalam kuesioner dianalisis dengan menggunakan skala $1-2,1-3$, dan $1-4$ sesuai dengan jenis pertanyaannya.

Teknik analisis data yang digunakan adalah analisis deskriptif persentase. Deskriptif presentase ini diolah dengan cara frekuensi dibagi dengan jumlah responden dikali 100\% seperti yang dikemukakan Sugiyono (2012) sebagai berikut:

$$
\mathrm{P}=\mathrm{F} / \mathrm{N} \times 100 \%
$$

Keterangan $\mathrm{P}$ adalah presentase jawaban, $\mathrm{F}$ adalah frekuensi nilai yang diperoleh dari seluruh item, $\mathrm{N}$ adalah jumlah responden, dan $100 \%$ adalah konstanta.

Kegiatan pembekalan dan pendalaman materi dilakukan di MTsN 6 Pesisir Selatan pada tanggal 8 April 2017. Kegiatan dilaksana kan dalam dua tahapan yaitu pemberian informasi dan diskusi. Pada tahap pemberikan informasi, pemateri memberikan materi secara interaktif meliputi pengetahuan tentang penulisan jurnal. Pada tahap diskusi, peserta dapat bertanya, mendapatkan masukan dan umpan balik seputar materi diskusi.

\section{HASIL DAN PEMBAHASAN}

Hasil analisis data angket dapat dijabar kan sebagai berikut:

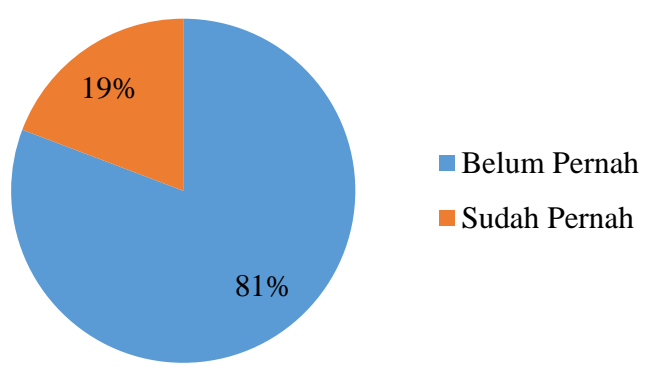

Gambar 1. Persentase Guru yang Pernah Menulis Artikel Ilmiah

Berdasarkan data pada Gambar 1, dari 26 guru yang ada di MTsN 6 Pesisir Selatan, hanya 5 guru yang pernah menulis artikel ilmiah, baik itu dalam bentuk PTK, makalah ataupun jurnal. Hal ini menunjukkan bahwa sebagian besar guru di sekolah belum memahami tentang penulisan karya tulis ilmiah. Selain itu, kurangnya minat menulis menyebabkan guru jarang menulis. Ada beberapa hal yang dapat menyebabkan guru kurang berminat dalam menulis. Pertama, banyak diantara guru-guru belum mempunyai budaya membaca yang baik. Kedua, motivasi yang rendah di kalangan guru-guru untuk menulis. Ketiga, guru-guru yang miskin gagasan. Keempat, kurangnya keberanian dalam menulis. 


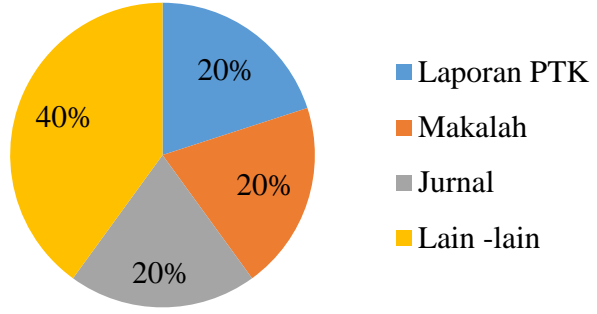

Gambar 2. Jenis Publikasi yang Pernah Ditulis

Gambar 2 menunjukkan jenis publikasi yang pernah ditulis oleh guru di MTsN 6 Pesisir Selatan. Publikasi ilmiah adalah menjadi pemasaran/narasumber pada forum ilmiah, melaksanakan publikasi ilmiah hasil penelitian atau gagasan ilmu pada bidang pendidikan formal baik berupa buku, karya tulis dalam majalah atau jurnal ilmiah, laporan, makalah, artikel ilmiah, modul/diklat dan karya hasil terjemahan.

Berdasarkan Buku Pedoman Penilaian Karya Ilmiah pada Forum Ilmiah Guru Tahun 2015 (Terbitan Depdiknas), terdapat 5 macam atau bentuk Karya Tulis Ilmiah untuk guru. Berikut 5 Macam Karya Tulis Ilmiah untuk guru antara lain: 1) penelitian kuantitatif uji hipotesis, pada penelitian ini menyajikan data kuantitatif (data angka) seperti pada skripsi maupun thesis pada umumnya, 2) Penelitian Tindakan Kelas (PTK) yang memiliki ciri utama adanya indikator keberhasilan dan desain penelitian berjenjang dari kegiatan pengamatan awal identifikasi masalah, kegiatan siklus 1 dan seterusnya hingga indikator keberhasilan tercapai atau terlampaui, 3) Penelitian Pengembangan Model, ciri utama memiliki Desain Pengembangan Model dilampiri contoh pengembangan instrumen, 4) penelitian Kualitatif, memiliki karakteristik adanya Kriteria Keabsahan Data (Deskriptif Kualitatif), 5) best Practices yang pada bab pembahasan memuat analisis permasalahan berdasarkan kajian pustaka dan didukung oleh data empiris di satuan pendidikan.

Secara umum, sistematika karya tulis ilmiah terdiri dari pendahuluan, kerangka teoritis, metodologi, hasil penelitian, pemba hasan, kesimpulan, dan saran. Berdasarkan Gambar 3, didapatkan kesimpulan bahwa 13 dari 26 guru belum mengetahui sistematika penulisan karya tulis ilmiah. Hal ini juga menjadi penyebab sedikitnya jumlah guru yang pernah menulis untuk publikasi.

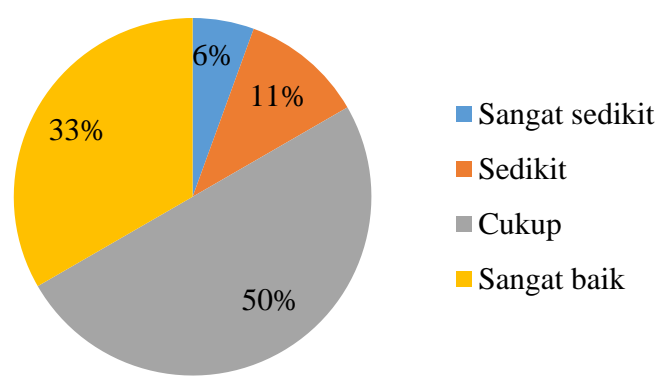

Gambar 3. Persentase Guru yang Mengetahui Sistematika Penulisan Karya Tulis Ilmiah

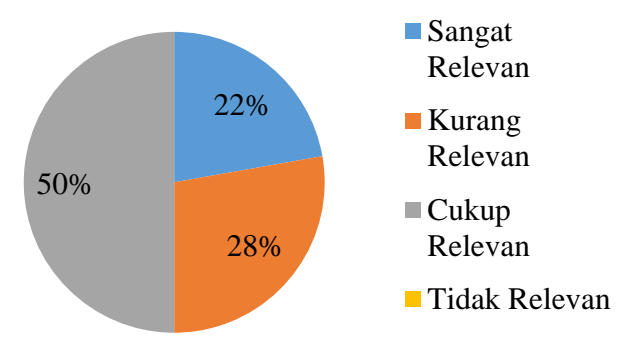

Gambar 4. Relevansi Materi Pelatihan dengan Kebutuhan Guru

Gambar 4 menunjukkan bahwa pelatihan penulisan karya tulis ilmiah sangat diperlukan guru karena cukup relevan dengan kebutuhan guru dalam mengurus kenaikan pangkat dan memperbaiki kualitas pembelajaran. Selama ini, guru menjadikan hasil belajar peserta didik sebagai acuan dalam keberhasilan guru dalam mengajar. Namun, guru kurang menyadari bahwa data hasil belajar peserta didik juga bisa dijadikan dasar untuk menyusun suatu tulisan yang dapat menjelaskan inovasi pembelajaran seperti metode, model, strategi pembelajaran.

Penulisan karya tulis ilmiah merupakan salah aspek peningkatan kemampuan pedagogik yaitu melakukan tindakan reflektif untuk peningkatan kualitas pembelajaran. Selain itu, penulisan karya tulis ilmiah dapat meningkatkan kompetensi kepribadian guru yang berkaitan dengan kemantapan dan integritas kepribadian 
seorang guru yaitu melaksanakan penelitian sederhana untuk keperluan pengajaran (Hawi, 2013: 6).

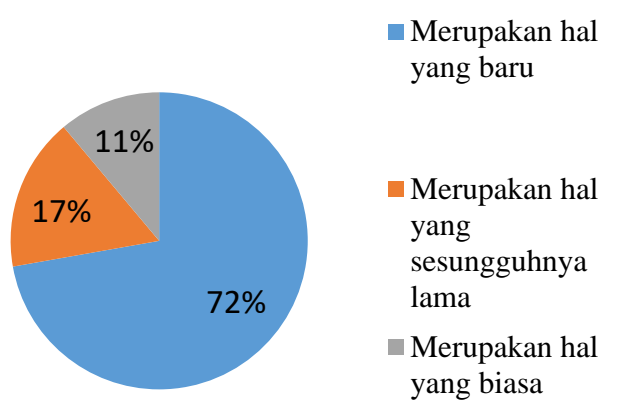

Gambar 5. Pendapat Guru Terhadap Materi Pelatihan

Walaupun sebenarnya pengetahuan tentang menulis karya ilmiah sudah pernah didapatkan oleh guru-guru, namun sebagian besar guru menyatakan bahwa materi pelatihan termasuk hal yang baru. Hal ini disebabkan oleh pelatihan penulisan karya tulis ilmiah tidak rutin dilaksanakan. Ilmu yang sudah pernah didapat kan tidak teraplikasi dengan baik sehingga guruguru masih menganggap menulis karya tulis ilmiah adalah sesuatu yang sulit dilakukan. Ditambah lagi dengan kesibukan guru dalam mengajar semakin menambah kesulitan guru dalam menulis.

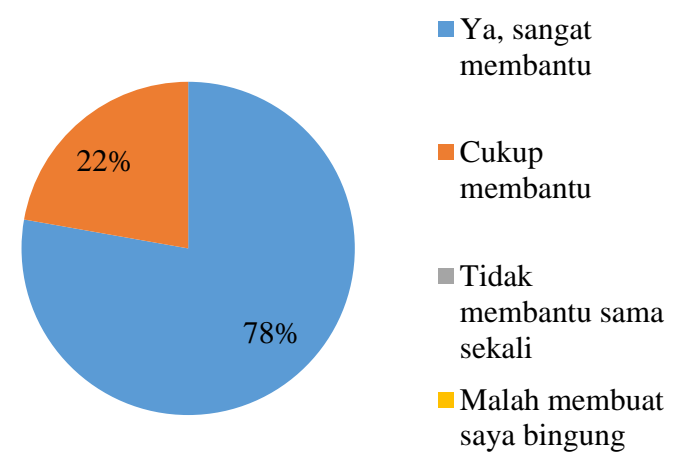

Gambar 6. Materi Pelatihan yang Diberikan Dapat Membantu Guru untuk Menulis Karya Ilmiah

Materi yang diberikan selama pelatihan mencakup jenis-jenis karya tulis ilmiah, sistematika karya tulis ilmiah, tips dan trik dalam menyusun karya tulis ilmiah. Penyam paian materi dilakukan dengan dua tahap yaitu presentasi dan diskusi. Guru dapat mengajukan pertanyaan yang terkait dengan penyusunan karya tulis ilmiah. Pertanyaan sebagian besar bersifat kontekstual sehingga solusi yang diberikan juga aplikatif bagi guru-guru.

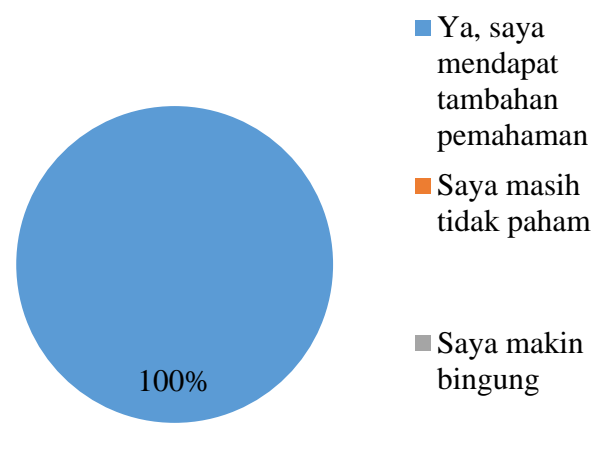

dan lain-lain

Gambar 7. Guru Memperoleh Tambahan Pema haman Tentang Penulisan Karya Ilmiah

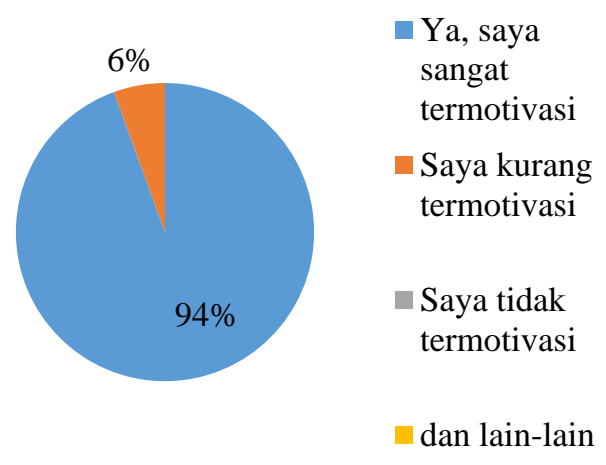

Gambar 8. Kegiatan Pelatihan Dapat Meningkat kan Motivasi Guru untuk Menulis Karya Ilmiah yang Lebih Baik

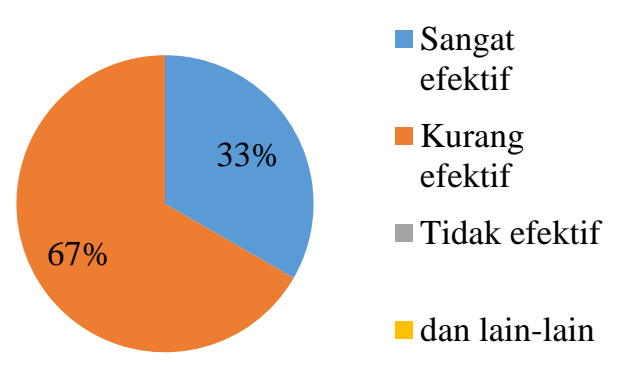

Gambar 9. Efektivitas Pelaksanaan Pelatihan 


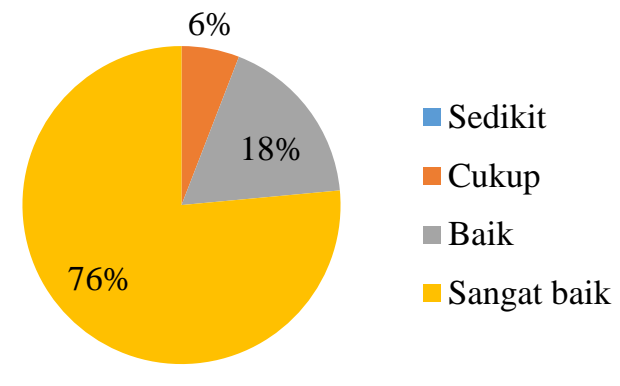

Gambar 10. Tingkat Pemahaman Guru terhadap Materi Pelatihan

Pelatihan yang diberikan menambah pemahaman guru mengenai cara menulis karya tulis ilmiah. Selain itu, guru juga diberikan informasi mengenai situs publikasi yang dapat mewadahi karya yang telah ditulis oleh guru misalnya jurnal berkala yang diterbitkan oleh MGMP Fisika Sumatera Barat dan seminar nasional dan internasional MIPA yang tiap tahun diadakan oleh FMIPA UNP.

Waktu pelatihan kurang efektif karena hanya berlangsung selama kurang lebih 2 jam (dari pukul 9 - 11 pagi). Pelatihan kurang maksimal mengingat guru-guru belum mempraktekkan teori yang di dapat ke dalam sebuah tulisan. Walaupun demikian, pema haman guru-guru terhadap materi pelatihan tergolong sangat baik. Hal ini karena pemateri telah menghimpun semua informasi yang dibutuhkan oleh guru dan dikemas untuk disajikan dalam waktu singkat sehingga guruguru dapat memahami maksud dari pelatihan ini dan mengaplikasikannya setelah pelatihan diberikan.

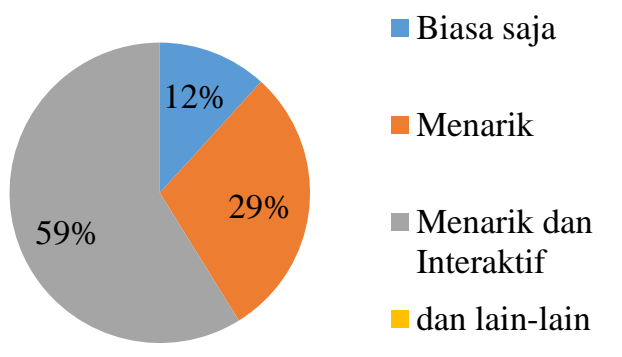

Gambar 11. Media yang Digunakan dalam Pela tihan Karya Tulis Ilmiah
Media pelatihan menggunakan program microsoft powerpoint. Slide presentasi terdiri dari 43 halaman (sudah termasuk cover dan penutup). Berikut adalah tampilan presentasi selama pelatihan.

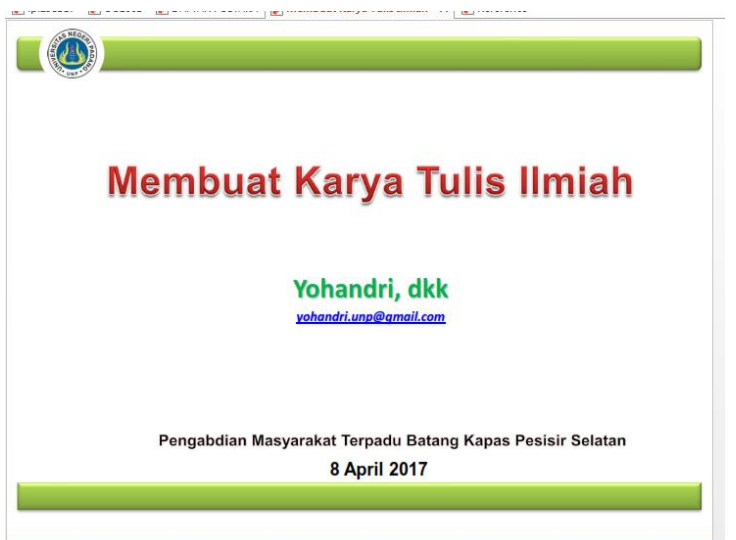

Gambar 12. Tampilan Awal Presentasi

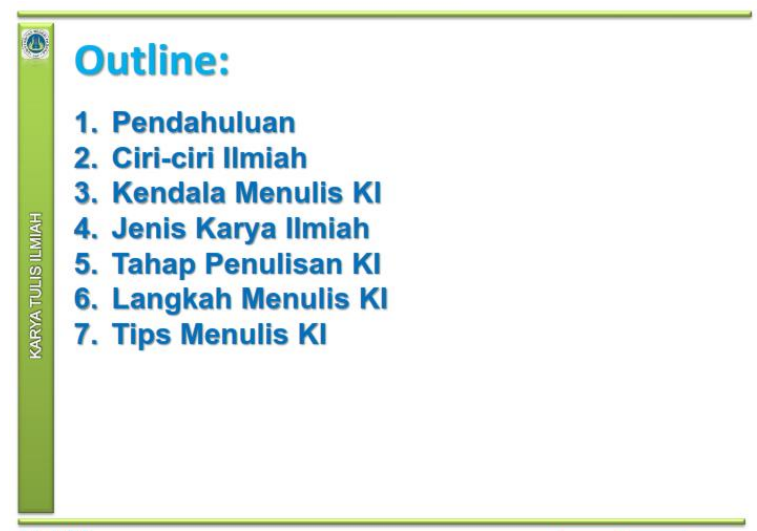

Gambar 13. Tampilan Outline Presentasi

Slide presentasi terdiri dari pendahuluan, ciri-ciri ilmiah, kendala menulis karya tulis, jenis karya ilmiah, tahap penulisan karya tulis, langkah menulis karya tulis, dan tips menulis karya tulis.

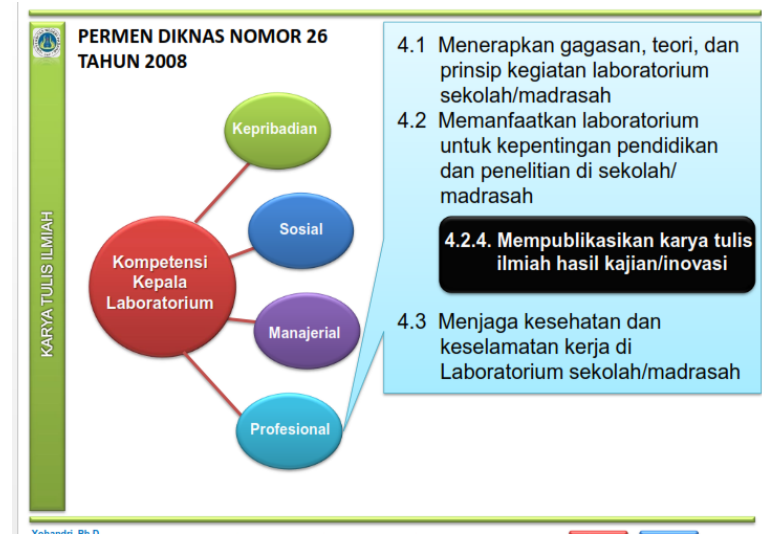

(a) 


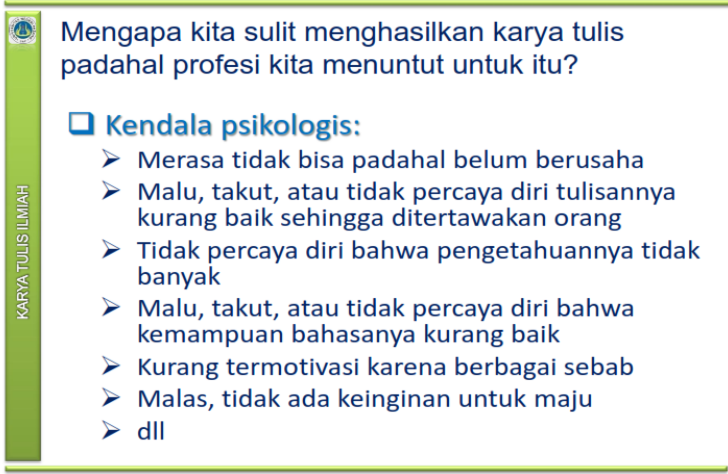

(b)

\section{Tahapan dalam menulis KI}

Secara umum ada tiga tahapan dalam menulis karya ilmiah, yakni :

(1) Tahap prapenulisan,

(2) Tahap penulisan, dan

(3) Tahap perbaikan (editing).

(c)

Gambar 14. Contoh Tampilan Isi Presentasi

Idealnya, seorang guru disamping mahir berbicara di depan kelas juga mahir menulis. Tetapi kenyataannya tidak berjalan seiring. Rata-rata guru mampu berbicara dengan dengan lancar dan lantang di depan kelas atau ketika memberikan pembinaan pada saat upacara bendera, tetapi ketika guru diminta untuk menulis, relatif banyak guru yang mengalami kesulitan.

Ada beberapa kendala yang dihadapi guru sehingga sulit menulis. Pertama, kesibukan guru mengajar menyebabkan guru kurang memiliki waktu untuk menulis. Tuntutan waktu mengajar menyebabkan guru kekurangan waktu untuk menyusun ide dan menjadikannya sebuah tulisan. Selain itu, guru juga disibukkan dengan menyusun program kerja tahunan dan bulanan, silabus, RPP, dan lain-lain. Banyaknya aktivitas menulis untuk memenuhi tuntatan administrasi membuat guru-guru tidak memiliki kesempatan lagi untuk menulis karya tulis ilmiah.

Kedua, guru tidak terbiasa menulis. Sebagian besar guru lebih senang menggunakan buku paket yang sudah ada daripada menyusun materi sendiri. Padahal buku paket yang tersedia belum tentu sesuai dengan kebutuhan peserta didik. Dengan tersedianya buku paket dari berbagai penulis, guru merasa puas dan melupakan bahwa dirinya harus terus menulis.

Ketiga, guru kurang percaya diri menulis karena khawatir tulisannya tidak berkualitas, ketinggalan jaman, tidak dimuat di surat kabar, dan kalah bersaing dengan penulis yang telah tenar. Keempat, guru malas menulis. Kesibukan guru mengajar di sekolah menyebabkan tenaga dan pikiran guru terkuras. Akibatnya, guru malas menulis.

Kelima, kurang berminat menulis. Menulis adalah aktivitas yang bermanfaat, tetapi dianggap bukan hal yang mudah untuk dilaksanakan sehingga menyebabkan guru kurang berminat untuk menulis. Keenam, merasa kurang memiliki kemampuan untuk menulis. Pada dasarnya setiap orang mampu menulis sebuah karya. Yang terpenting adalah bagaimana untuk mengasah kemampuan tersebut.

Ketujuh, tidak memiliki ide untuk dijadikan sebuah tulisan. Guru dengan berbagai aktivitas pembelajaran di sekolah seharusnya menyadari bahwa setiap tindakan yang dilakukan di sekolah dapat menjadi sebuah tulisan. Seorang guru dapat menyusun sebuah PTK yang merekam aktivitas peserta didik dalam beberapa pertemuan. Seorang guru yang kreatif dapat menciptakan suatu karya hanya dengan menerapkan inovasi pembelajaran. Namun, permasalahannya adalah guru belum menyadari hal itu.

Kedelapan, ketika memiliki ide untuk menulis, tidak mampu mengembangkannya karena tidak memiliki referensi yang cukup untuk menunjang tulisan. Untuk dapat mencip takan tulisan yang baik, seorang guru harus banyak mencari literatur di perpustakaan ataupun di internet. Oleh karenanya, penting bagi seorang guru untuk terus mengikuti perkem bangan teknologi.

Untuk mengatasi berbagai kendala yang dihadapi guru yang mengalami kesulitan dalam menulis, khususnya menulis artikel, penulis menawarkan beberapa upaya. Pertama, luangkan waktu untuk menulis walaupun hanya satu jam setiap harinya. Menulis dapat dimulai dari hal yang sederhana yaitu menulis ide-ide kreatif di dalam sebuah buku catatan. Ide-ide tersebut dapat menjadi dasar dalam penulisan karya tulis ilmiah.

Kedua, memperbanyak latihan dan membiasakan diri dalam menulis. Menjaga konsisten dalam menulis dapat meningkatkan 
kemampuan menulis. Tetap menulis walaupun banyak kesalahan yang di awal. Kesalahan tersebut menjadi permulaan tulisan yang lebih baik.

Ketiga, memperbanyak membaca buku tentang teknik menulis artikel. Keempat, banyak mengikuti seminar atau pelatihan tentang dunia kepenulisan. Kelima, banyak berdiskusi dengan penulis yang dinilai telah mahir. Keenam, banyak membaca buku referensi dan artikel tentang topik yang akan ditulis. Terakhir, banyak mengikuti perkembangan informasi dari media massa.

Membuat karya ilmiah bagi guru memang tidak mudah mengingat guru diberi beban mengajar minimal 24 jam perminggu selain itu tugas yang diemban sebagai pendidik dan pengajar cukup berat ditambah peran guru dalam kegiatan sosial kemasyarakatan yang menumpuk. Namun dilain pihak guru harus membuat dalam memenuhi kewajibannya jika ingin naik golongan dan pangkat. Lebih dari sekedar pemenuhan persyaratan kenaikan pangkat/jabatan, menulis karya ilmiah dan berbagai kegiatan pengembangan profesi lain nya. sebaiknya senantiasa dilakukan oleh para guru sebagai anggota profesi.

Profesi apapun, kemapanan dan ke matangannya sangat bergantung pada 'kiprah' anggotanya. Contoh, tinggi rendahnya penga kuan dan penghargaan masyarakat terhadap profesi guru, sangat tergantung dari profesio nalitas guru dalam melaksanakan tugasnya yaitu mendidik, mengajar, dan dari sisi hasil yaitu berbagai jenis karya tulis ilmiah guru seperti buku pelajaran, modul, artikel, laporan penelitian, media pendidikan, diktat dan lainlain yang sangat bermanfaat bagi dunia pendidikan. Berbagai karya guru tersebut akan menguatkan eksistensi profesi guru. Dengan demikian, kegiatan pengembangan profesi, dalam hal ini menulis karya tulis ilmiah hendaknya dipandang sebagai bagian integral tugas, kewajiban, dan tangung jawab setiap guru.

\section{KESIMPULAN}

Kesimpulan dari penelitian ini adalah pemberian pembekalan dan pendalaman materi tentang penulisan karya tulis ilmiah untuk guruguru MTsN 6 Pesisir Selatan dapat mening katkan IPTEK masyarakat dalam penulisan karya tulis ilmiah serta dapat mewujudkan guru yang profesional. Hal ini ditandai dengan 1) pelaksanaan pelatihan dapat menambah pemahaman guru tentang penulisan karya tulis ilmiah, dan 2) materi yang disampaikan selama pelatihan dapat memotivasi guru di MTsN 6 Pesisir Selatan untuk menulis karya tulis ilmiah yang diangkatkan dari permasalahan yang ditermukan di dalam kelas.

\section{DAFTAR PUSTAKA}

Buku Pedoman Penilaian Karya Ilmiah pada Forum Ilmiah Guru Tahun 2015 (Terbitan Depdiknas)

Hawi, Akmal. 2013. Kompetensi Guru Pendidikan Agama Islam. Jakarta: PT Raja Grafindo Persada

Misbahudin. 2013. Analisis Data Penelitian dengan Statistik. Jakarta: Bumi Aksara Jakarta

Mudhafir, Ali. Pendidik Profesional (Konsep, Strategi dan Aplikasinya Dalam Peningkatan Mutu Pendidik di Indonesia). Jakarta: Rajawali Press

Peraturan Menteri Negara Pendayagunaan Aparatur Negara dan Reformasi Birokrasi Nomor PER/16/M.PAN-RB/11/2009 tentang Jabatan Fungsional Guru dan Angka Kreditnya

Ramayulis. 2013. Profesi dan Etika Keguruan. Jakarta: Kalam Mulia

Setiadi. 2015. Publikasi Ilmiah Guru. Yogyakarta: Deepublish

Sugiyono. 2012. Metode Penelitian Kuantitatif Kualititatif dan R\&D. Bandung: Alfabeta

Tim Penulis Jurnal Pendidikan Sains. 2013. Pengembangan Profesionalitas Berkelanjut an/CPD Guru Bersertifikat Pendidik di SMK Rumpun Teknologi se-Malang Raya. Malang: UNM

Undang-Undang Dasar Republik Indonesia Tahun 1945

Undang-Undang Nomor 14 Tahun 2005 tentang Guru dan Dosen

Undang-Undang Nomor 20 Tahun 2003 Tentang Sistem Pendidikan Nasional

Usman, Uzer. 2011. Menjadi Guru Profesional. Bandung: Remaja Rosdakarya

Wiyanto, Asul. Panduan Karya Tulis Guru. Yogyakarta: Pustaka Ghratama

Yahya, Murip. 2013. Profesi dan Tenaga Kependidikan. Bandung: Pustaka Setia 